\title{
CORRESPONDENCE
}

\section{Two good reasons to reject the PWR}

SIR, - Sir Alan Cottrell (Nature, 28 February, page 804 ) has put his finger on the principal weaknesses of the PWR - the two-phase coolant and the pressure vessel failure problem - either of which is a cause for doubting the wisdom of adopting this reactor for the UK. Taken together they are sufficient reason for abandoning the idea completely. One might wonder why our electricity authorities are so keen to get into the PWR business at all.

Power station construction engineers are perhaps the main pressure group. They have not performed well with the AGR for many reasons, including starting construction long before the design was ready, and trying to develop and prove major components as they went along. The resulting delays and cost increases are well known, and technical difficulties have been introduced that have caused poor operating records in the early life of finished stations. Now, with remarkable lack of introspection, the same engineers are identifying the culprit as the AGR itself; amongst other things, they say, it is too complicated mechanically and needs too much work on site. They regard PWR as the solution to their problems (or should we say shortcomings), for they have convinced themselves that it is much easier to build than the AGR. This is the dangerous sort of complacency that led to the Dungeness B fiasco, which was very nearly repeated with SGHWR.

The AGR is based on sound principles, uses good materials of construction, and has excellent safety and operating characteristics. This is a recipe for success but it does need first class detailed design and project engineering. So does any other type of reactor It is no good running away from the gascooled reactors because it is thought, wrongly, that the PWR is an easier option. This simply wastes our limited technical resources to promote a reactor with some frankly undesirable properties. The better course is to recognise our failings, capitalise on experience and concentrate our best professional efforts on making AGR the successful UK thermal reactor that it can now be. Yours faithfully, DR. C. P. HAIGH

Painswick

Old Snead Park

Bristol 9

Dr. C. P. Haigh was founder and for 14 years Director of the Berkeley Nuclear Laboratories of the CEGB. Subsequently he was responsible for overseeing the design of $C E G B$ generating plant, including the nuclear reactors

\section{Concentrating ethanol}

SIR, - The amount of energy used in distilling off ethanol has not escaped attention to quite the extent that Taylor (Nature, 17 January, page 714) suggests, (see E.V. Anderson, Chem. Engng News, 31 July, 1978, page 8). In a simple still, nearly as much energy is discharged in the cooling water as is available from the ethanol. This waste of energy can be greatly diminished, at a price, by using multiple effect or vapour compression distillation units. Vapour compression is particularly attractive because ethanol could then be continuously removed from the fermentation mixture at low pressure so that its inhibiting action on yeast fermentation would be minimised.

There are various alternatives to distillation. The most interesting is the use of a semipermeable membrane. Thomas Graham, in the paper (Phil. Trans. Roy. Soc. 151, 183, 1861) in which he introduced the word 'colloid', mentions "the well-known bladder experiment of Sormmering"'. He gives no reference, but explains that the permeability of bladder is selective and water evaporates from the outside so that more concentrated ethano remains within. This may well have been a traditional technique in Europe.

Geoffrey Gorer (Himalayan Village, $\mathrm{M}$ Joseph, 1938) says that beer is hung up in pieces of gut in Bhutan so as to make a more potent drink. Perhaps we still have something to learn from primitive technology. Yours faithfully,

42 Leyton Rd, Harpenden

\section{Soviet biotechnology}

SIR, - Recently there has been a number of comments in Nature about biotechnology. In the issue of 10 January, (page 123) there was an attempt to assess the world situation in which, for instance, Japan was quoted as a world leader in this field; we would not dispute this claim. However, that "most socialist countries ... . are somewhat secretive as to detail" is a slightly misleading conclusion.

Whilst we were preparing the Society for General Microbiology Symposium on Microbial Technology in 1979 it came to our attention that the Soviet Union and other communist bloc countries also were becoming increasingly active in biotechnology. In 1978 , for example, President Brezhnev at the 25th Party Congress cited the microbiological industry as a key growth area in the Soviet economy, the aim during the current five-year plan being to develop microbiological industry four times faster than any other sector of industrial activities.

The degree of commitment to biotechnology in the USSR can be judged by reference to just one programme, namely single cell protein (SCP) production. In 1977 Academician N.M. Zhavoronkov announced that the production of fodder yeast from various internally available raw materials was being planned to make the USSR self-sufficient in protein feedstuffs for animals by 1990 . The 1980 forecast for SCP production in the Soviet Union is of the order four million tons per annum, a figure that makes interesting comparison with the UK's largest programme, the ICI "Pruteen" project, which should come on stream this year and is expected to produce 50,000 tons per annum. Yours faithfully,

ALAN T. BULL

Department of Applied Biology, UWIST DEREK C. ELLWOOD

Centre for Applied Microbiology and Research, Porton

Colin RatLEDGE Department of Biochemistry, University of Hull

\section{Sakharov's plight}

StR,- The recent action of the Soviet authorities against our distinguished colleague academician Andrei Sakharov provides another testimony about the increasing violations of human rights and civil freedoms in the USSR.

One can understand (though not agree with) the decree of the Presidium of the Supreme Soviet of the USSR depriving Professor Sakharov of his numerous decorations. For scientists, however, it is difficult to understand the meaning of the decision of the Council of Ministers of the USSR, by which all the state prizes Andrei Sakharov was awarded in the last 25 years, have been taken away from him. Is he supposed to pay back the substantial amount of money which accompanied each of these prizes? Does the Soviet government really think that its decree will make Sakharov's discoveries (like the physical principles for fusion reactors) non-existent or even invalid? Or that Andrei Sakharov will, by the decree of Soviet government, cease to be the author of them? For the first time Soviet reality has surpassed Orwell's visions.

Internal exile to Gorky deprives Sakharov of one of the main rights and privileges of the members of Soviet Academy of Sciences to have the conditions for carrying on his scientific research. It is not clear yet, whether the Soviet Academy is going to propose the expulsion of Sakharov from its membership, but it should be made quite clear in advance that such a step would have most harmful consequences upon international collaboration and contacts in science. Yours faithfully,

FRANTISEK JANOUCH

Research Institute of Physics, Stockholm, Sweden

\section{Disposal of carcinogens}

SIR, - The International Agency for Research on Cancer (IARC), with the support of the Office of Research Safety of the National Cancer Institute, has recently undertaken a programme of research on the disposal of laboratory wastes containing carcinogens, which will give specific instructions for destruction and disposal of the various carcinogenic wastes from laboratories.

We give here a brief résumé of a meeting of the working group responsible for establishing guidelines and priorities for the programme. We welcome comments, information related to similar work being carried out in other laboratories, and suggestions for active collaboration in the programme. As resources available for work of this nature tend to have a lower priority than original work on carcinogenicity, it is particularly essential that available knowledge is pooled.

In discussing a general strategy for control of carcinogenic waste, the working group: - emphasised that experiments involving carcinogens should be designed in such a way as to minimize the quantities of hazardous material used;

recognised that the scale of operations varied with different types of experiments; - stressed that a waste treatment should yield for disposal products having minimum adverse biological or environmental effects;

- recommended that control techniques

should, as far as possible, be carried out at the experimental site to minimize transportation, which may involve a public risk; and

insisted that an experimental plan should contain the action to be taken in the event of a substance escaping from control in the course of an experiment.

A waste control strategy must take into account both the types of material for which appropriate treatment would be required, as well as their comparative importance in terms of risk of exposure during manipulation.

In discussing possible approaches to waste destruction, it was recognised that properly designed incineration techniques require careful attention to a number of variables such as temperature of operations, air supply and feed rate. An alternative approach is to develop suitable chemical reactions which yield non-hazardous products.

From a list of carcinogens to be considered in a destruction programme, aflatoxins, nitrosamines and polycyclic aromatic hydrocarbons were selected as the immediate priorities for investigation. Alkylating agents, halogenated compounds, aromatic amines and hydrazines were also considered as high priorities.

Yours faithfully, E.A. Walker, M. Castegnaro, Unit of Environmental Carcinogens, International Agency for Research on Cancer, 150 Cours Albert Thomas, 69372 Lyon Cédex 2, France 